\title{
Momordica cochinchinensis Spreng. seed extract suppresses breast cancer growth by inducing cell cycle arrest and apoptosis
}

\author{
LEI ZHENG $^{1,2}$, YANMIN ZHANG ${ }^{1}$, YANPING LIU ${ }^{1}$, XIAOYAN OU YANG $^{1}$ and YINGZHUAN ZHAN ${ }^{1}$ \\ ${ }^{1}$ School of Pharmacy, Health Science Center, Xi'an Jiaotong University, Xi'an, Shaanxi 710061; \\ ${ }^{2}$ School of Pharmaceutical Sciences, Xi'an Medical University, Xi'an, Shaanxi 710021, P.R. China
}

Received September 15, 2014; Accepted June 5, 2015

DOI: $10.3892 / \mathrm{mmr} .2015 .4186$

\begin{abstract}
The herb Momordica cochinchinensis has been used for a variety of purposes, and been shown to have anti-cancer properties. The present study assessed the potency and the underlying mechanisms of action of the ethyl acetate extract of seeds of Momordica cochinchinensis (ESMC2) on breast cancer cells. Therefore, the effects of ESMC2 on the cell viability, cell cycle and apoptosis of MDA-MB-231 cells were investigated. The results showed that ESMC2 exerted a marked growth inhibitory effect on the cells. Cell cycle arrest in G2 phase following treatment with ESMC2 was associated with a marked increase in the protein levels of cyclin B1, cyclin $\mathrm{E}$ and cyclin-dependent kinase 1 and a decrease in cyclin D1 expression. In addition, ESMC2 dose-dependently induced cell apoptosis, which was mediated via upregulation of the apoptosis-associated proteins p53, B-cell lymphoma 2 (Bcl-2)-associated $\mathrm{X}$ protein, $\mathrm{Bcl}-2$ homologous antagonist killer and Bcl-2-associated death promoter expression, as well as downregulation of nuclear factor kappa B, Bcl-2 and myeloid cell leukemia-1. Furthermore, the activation of extracellular signal-regulated kinase $1 / 2$, p38, c-Jun N-terminal kinase (JNK) and Akt phosphorylation were decreased by ESMC2 in a dose-dependent manner, indicating that ESMC2 exerted its effects via the mitogen-activated protein kinase/JNK pathway. Furthermore, nude mouse xenotransplant models were used to evaluate the tumor growth inhibitory effects of ESMC2. The possible chemical components of ESMC2 were analyzed by gas chromatography-mass spectrometry, and 12 compounds were detected from the major peaks based on the similarity index with entries of a compound database. The results of the
\end{abstract}

Correspondence to: Dr Yingzhuan Zhan, School of Pharmacy, Health Science Center, Xi'an Jiaotong University, 76 Yanta West Street, Xi'an, Shaanxi 710061, P.R. China

E-mail: zyzlt2009@mail.xjtu.edu.cn

Key words: Momordica cochinchinensis, breast cancer, cell cycle, apoptosis, xenotransplant models, gas chromatography mass spectrometry present study may aid in the development of novel therapies for breast cancer.

\section{Introduction}

Medicinal plants are valuable sources for the discovery of novel lead compounds and novel chemical entities with anti-cancer properties. Significant effort has been made to identify compounds or herbs that kill tumors $(1,2)$. The search for anti-cancer agents in plant sources started in the $1950 \mathrm{~s}$ with the discovery and development of the vinca alkaloids vinblastine and vincristine, and the isolation of the cytotoxic podophyllotoxins (3).

Momordica cochinchinensis Spreng., a member of the Cucurbitaceae family and an underutilized perennial dioecious vegetable, has been highly valued for its nutritional and medicinal qualities and wide range of uses. Its fruit and seeds have been part of an indigenous diet, and the plant has been used as a traditional medicine throughout East and Southeast Asia for a long time $(4,5)$. In the various Asian languages, the fruit is called Gac in Vietnam, Fak kao in Thailand, Bhat kerala in India, Mu Bie Zi in China and Mak kao in Laos (6). The ripened seeds with a palatable taste, cooked to impart its red color, are traditionally used in Vietnamese cuisine in the dish 'Xoi Gac' made for weddings and New Year celebrations (4). The seeds of the fruit are used in Traditional Chinese Medicine and have various pharmacological actions against conditions including boils, pyodermatitis, mastitis, tuberculous cervical lymphadenitis, ringworm infections, freckles, sebaceous, hemorrhoids and hemangiomas; furthermore, they have immune-stimulating, anti-oxidant, anti-inflammatory and anti-cancer actions $(6,7)$

To date, the effects of Momordica cochinchinensis on breast cancer cells have not been investigated. In the present study, the effect of the ethyl acetate extract of Momordica cochinchinensis (ESMC2) on the growth of breast cancer cells was assessed. Furthermore, the underlying mechanisms of the anti-proliferative action of ESMC2 on breast cancer cells were assessed.

The modulation of the expression of cell-cycle regulatory proteins following treatment with anti-proliferative and apoptosis-inducing compound has been reported by numerous 
studies (8-10). Cyclin (CCN)-dependent kinases (Cdks), evolutionarily conserved proteins, are essential for cell cycle control, and distinct pairs of cyclins and cdks regulate progression in various stages of the cell cycle (11).

The ability of ESMC2 to inhibit cell proliferation and cause cell cycle arrest, which is associated with apoptosis, was assessed in the present study. Apoptosis, characterized by a series of molecular signaling processes, is the major form of programmed cell death and has critical roles in cancer. It can be triggered by diverse intracellular signals that act upon the B-cell lymphoma 2 (Bcl-2) protein family, which can be divided into two groups: Suppressors of apoptosis [including Bcl-2, Bcl-extra large protein and myeloid cell leukemia-1 (Mcl1)] and activators of apoptosis [including Bcl-2-associated $\mathrm{X}$ protein (Bax), Bcl-2 homologous antagonist killer (Bak) and Bcl-2-associated death promoter (Bad)] (12). In addition, cell transformation often involves activation of pro-survival pathways contributing to uncontrolled cell growth. Cell survival is mediated by the phosphoinositide 3-kinase-mediated activation of the anti-apoptotic kinase Akt $(13,14)$. Three major members of mitogen-activated protein kinases (MAPKs), P38, c-Jun N-terminal kinase (JNK) and extracellular signal-regulated kinase (Erk)1/2, have also been shown to regulate apoptosis (15-17). Akt in turn phosphorylates and inhibits the pro-apoptotic proteins. Therefore, Akt and Erk1/2 are key junction points linking together signal transduction involved in survival and proliferation (18). Suppression of p53 and constitutive activation of nuclear factor kappa B (NF- $\mathrm{B})$ are considered as potential targets for therapeutic intervention aimed at selective elimination of cancer cells (19-21).

The present study examined the anti-tumor activities of Momordica cochinchinensis Spreng. seeds in vitro as well as in vivo. The chemical composition of ESMC2 was also analyzed by gas chromatography-mass spectrometry (GC/MS). The results of the present study scientifically validated the efficacy of the traditional medicinal plant Momordica cochinchinensis Spreng. and provided a basis for its application in anti-cancer therapy.

\section{Materials and methods}

Materials. Cell culture mediums (L-15), trypsin, MTT, dimethyl sulfoxide (DMSO), RNase, propidium iodide (PI), Annexin-V-fluorescein isothiocyanate (FITC), Hoechst 33258 and rhodamine 123 were purchased from Sigma-Aldrich (St. Louis, MO, USA). Protease inhibitor cocktail and phosphatase inhibitor cocktail were purchased from Roche (Basel, Switzerland). Fetal bovine serum (FBS) was purchased from Lanzhou National Hyclone Bio-Engineering Co., Ltd. (Lanzhou, China). ERK1/2 rabbit monoclonal antibody (mAb) [immunoglobulin (Ig)G; cat no. 4695], phospho ERK1/2 rabbit mAb (IgG; cat no 4370), AKT rabbit mAb (IgG; cat no. 4691), phospho AKT rabbit $\mathrm{mAb}$ (IgG; cat no 4060), phospho p38 rabbit $\mathrm{mAb}$ (IgG; cat no. 4511) were obtained from Proteintech Group (Chicago, IL, USA). Goat anti-mouse IgG-horseradish peroxidase (HRP) (cat no. sc-2005) and goat anti-rabbit IgG-HRP (cat no. sc-2004) were obtained from Santa Cruz Biotechnology (Dallas, TX, USA). All high-performance liquid chromatography (HPLC)-grade solvents were obtained from Fisher Thermo Scientific (Pittsburgh, PA, USA). The
HPLC-grade water was purified by a MK-459 Millipore Milli-Q Plus ultrapure water system (Milford, MA, USA).

Plant materials. Momordica cochinchinensis Spreng. seeds were collected in Xi'an (China) in June 2011 and identified by Dr Xiaofeng Niu, School of Pharmacy, Xi'an Jiaotong University (Xi'an, China). A voucher specimen (no. 11119) is deposited at the Institute of Materia Medica, School of Medicine, Xi'an Jiaotong University, China (Xi'an, China).

Extraction method. The Soxhlet extraction method, one of the oldest techniques of solid sample preparation for isolation of natural products, has been the most used extraction technique worldwide for a number of decades $(22,23)$. The seeds of Momordica cochinchinensis were ground into fine powder by a grinder (FW100; Taisite Instrument Co., Ltd., Tianjin, China). Subsequently, the Soxhlet extraction method using a Soxhlet extractor (YMST-250S; Shanghai YuMing YiQi Co., Ltd., Shanghai, China) with a series of solvents with an increasing polarity gradient, including hexane, ethyl acetate, acetone, ethanol and water, was applied. Firstly, $50 \mathrm{~g}$ Momordica cochinchinensis powder was decocted in each solvent $(500 \mathrm{ml})$ in the indicated sequence (from heaxane to water) for $8 \mathrm{~h}$ each. The individual extracts were filtered through a qualitative filter paper with $30-50 \mu \mathrm{M}$ pore size (Hangzhou Special Paper Industry Co., Ltd., Hangzhou, China) in a funnel and collected. Finally, the extracts were concentrated using a rotary evaporator (RE-52A; Shanghai YaRong Biochemistry Instrument, Shanghai, China) and named as ESMC1-5 according the order of extraction, respectively. The weight of the extracted material of fraction 2 was $0.53 \mathrm{~g}$ with an extraction yield of $1.06 \%$. The dry powder was dissolved with DMSO at $100 \mathrm{mg} / \mathrm{ml}$ and stored at $4^{\circ} \mathrm{C}$. The stock solution was further diluted with serum-free L15 medium immediately before use.

Identification and chemical analysis using GC/MS. A GC/MS (GCMS-QP2010; Shimadzu, Kyoto, Japan) with a Shimadzu AOC-20i auto-sampler system, and a Rtx-5 ms column (30 m x $0.25 \mathrm{~mm}$ internal diameter; film thickness, $0.25 \mu \mathrm{m}$; Restek, Bellefonte, PA, USA) were used. The column oven was programmed from 80 to $120^{\circ} \mathrm{C}$ at a rate of $10^{\circ} \mathrm{C} / \mathrm{min}$, then to $180^{\circ} \mathrm{C}$ at $5^{\circ} \mathrm{C} / \mathrm{min}$, then to $240^{\circ} \mathrm{C}(5 \mathrm{~min})$ at $10^{\circ} \mathrm{C} / \mathrm{min}$, and finally to $280^{\circ} \mathrm{C}(5 \mathrm{~min})$ at $5^{\circ} \mathrm{C} / \mathrm{min}$. The inlet temperature was kept at $280^{\circ} \mathrm{C}$. Helium carrier gas was used at a constant flow rate of $1.18 \mathrm{ml} / \mathrm{min}$. A sample of $1 \mu \mathrm{l}$ was injected, and the split ratio of the injector was 10:1. MS conditions were as follows: Ionization energy, $70 \mathrm{eV}$; ion source temperature, $200^{\circ} \mathrm{C}$; and full-scan mode in the range of $\mathrm{m} / \mathrm{z}$ 50-600 with $0.5 \mathrm{sec} / \mathrm{scan}$ velocity. The major components in this sample were predicted by the National Institutes of Standard and Technology (NIST) mass spectral library, V.8.0 (Shimadzu, Kyoto, Japan).

Cell culture and animals. Human breast cancer MDA-MB-231 cells were obtained from the Shanghai Institute of Cell Biology of the Chinese Academy of Sciences (Shanghai, China) and were cultured in L-15 supplemented with $10 \%$ (v/v) FBS and incubated at $37^{\circ} \mathrm{C}$ with $5 \% \mathrm{CO}_{2}$. Cells in the logarithmic growth phase of growth were used for the experiments. 
A total of 24 six-week-old female BALB/c-nu/nu nude mice (body weight, 16-18 g) were purchased from the Shanghai Institute of Experimental Animals of the Chinese Academy of Sciences (Shanghai, China). Animals were maintained under specific pathogen-free conditions at $25^{\circ} \mathrm{C}$ in $50-70 \%$ humidity with a 12-h light/dark cycle and had access to sterile food and water.

Cell proliferation assay. The effect of ESMC2 on MDA-MB-231 cell proliferation was evaluated by an MTT assay. Exponentially growing cells were seeded into 96-well plates at a density of $2 \times 10^{4}$ cells per well in medium. After $24 \mathrm{~h}$ of incubation at $37^{\circ} \mathrm{C}$, cells were treated with ESMC2 at various concentrations $(8,15,30,60,120$ or $250 \mu \mathrm{g} / \mathrm{ml})$ for $48 \mathrm{~h}$. Subsequently, $20 \mu \mathrm{l}$ MTT $(5 \mathrm{mg} / \mathrm{ml})$ was added to each well and cells were incubated at $37^{\circ} \mathrm{C}$ for $4 \mathrm{~h}$. After removal of the medium, $150 \mu \mathrm{l}$ DMSO was added to each well, and the optical density of the cells was determined with a microplate reader (model 550; Bio-Rad Laboratories, Hercules, CA, USA) at $490 \mathrm{~nm}$. The cell viability was expressed in absorbance units (24).

PI staining assay. Cell death was assessed using a PI staining assay. MDA-MB-231 cells were trypsinized after treatment with ESMC2 at various concentrations for $48 \mathrm{~h}$ and then cells were collected and re-suspended in $1 \mathrm{ml}$ phosphate-buffered saline (PBS). Cells were stained with $0.5 \mathrm{ml}$ staining solution (50 mg/ml PI, $100 \mathrm{mg} / \mathrm{ml}$ RNase, $0.2 \%$ Triton X-100) and cells were incubated in $37^{\circ} \mathrm{C}$ for $30 \mathrm{~min}$ in the dark. Cell death was measured by flow cytometry (FACSCalibur; BD Biosciences, Franklin Lakes, NJ, USA) (25).

DNA morphological observation by Hoechst staining assay. To visualize apoptotic cell death and nuclear morphology, cells were stained with Hoechst 33258. The number of apoptotic cells was measured by assessing the percentage of cells displaying chromatin condensation within the total cell population. Briefly, MDA-MB-231 cells were seeded in six-well plates (cat no. 3516; Corning-Costar, Corning, NY, USA) containing cover slips and treated with ESMC2 at various concentrations. After $48 \mathrm{~h}$ of treatment, cells were collected washed with PBS and allowed to dry on the slides. Genomic DNA was stained with Hoechst 33258 for $10 \mathrm{~min}$ at $37^{\circ} \mathrm{C}$ according to the manufacturer's instructions. Approximately 300 nuclei were counted per sample under a fluorescence microscope (Ti-U; Nikon, Tokyo, Japan) (26).

Analysis of cell apoptosis. MDA-MB-231 cells were treated with ESMC2 at various concentrations for $48 \mathrm{~h}$, and were then collected, washed and re-suspended in PBS. The apoptotic cell death rate was examined with Annexin V-FITC and PI double staining (5 $\mu \mathrm{l}$ Annexin V-FITC, $10 \mu \mathrm{l}$ PI for $15 \mathrm{~min}$ in the dark) according to the manufacturer's instructions. The cell suspension was then analyzed by flow cytometry (27).

Cell cycle analysis. For analysis of the cell cycle, MDA-MB-231 cells were stained with PI as previously described (28). MDA-MB-231 cells were treated with ESMC2 at the indicated concentrations. After $48 \mathrm{~h}$ of incubation, cells were trypsinized, collected, washed in PBS, and subsequently fixed in $70 \%$ ethanol. Following incubation with RNase $(50 \mu \mathrm{g} / \mathrm{ml})$ and PI $(60 \mu \mathrm{g} / \mathrm{ml})$ in the dark at room temperature for $30 \mathrm{~min}$, the cell suspension was analyzed by flow cytometry (29).

Determination of the mitochondrial transmembrane potential $\left(\Delta \Psi_{m}\right)$. The changes in the $\Delta \Psi_{\mathrm{m}}$ were determined by the retention of the dye rhodamine 123. For fluorescence microscopic imaging, MDA-MB-231 cells were seeded in a six-well chamber slide at a density of $2 \times 10^{5}$ cells/well. After treatment with 30, 60 and $120 \mu \mathrm{g} / \mathrm{ml}$ ESMC2 for $48 \mathrm{~h}$, cells were washed with L15 medium twice. The wells were loaded with freshly-prepared rhodamine 123 solution $(1 \mathrm{mM})$ and further incubated at $37^{\circ} \mathrm{C}$ for $30 \mathrm{~min}$. Following washing, rhodamine 123 fluorescence was measured by flow cytometry with excitation and emission wavelengths of 488 and $530 \mathrm{~nm}(30)$.

Western blot analysis. MDA-MB-231 cells incubated with ESMC2 were analyzed by western blot analysis. MDA-MB-231 cells treated with ESMC2 at various concentrations for $48 \mathrm{~h}$ were lysed with lysis buffer (C1053; Applygen, Beijing, China) containing protease inhibitor cocktail and phosphate inhibitor cocktail on ice for $30 \mathrm{~min}$. The lysate was then collected, and centrifuged at $12,000 \mathrm{xg}$ and $4^{\circ} \mathrm{C}$ for $10 \mathrm{~min}$. The protein lysates were resolved by $10 \%$ SDS-PAGE and separated proteins were transferred onto polyvinylidene difluoride membranes and blocked with $5 \%$ skimmed milk for $2 \mathrm{~h}$. The membranes were then incubated with specific primary antibodies overnight at $4^{\circ} \mathrm{C}$. The primary antibodies included anti-ERK1/2 (1:1,000 dilution), anti-phospho ERK1/2 (1:1,000 dilution), anti-AKT (1:1,000 dilution), anti-phospho AKT (1:1,000 dilution), anti-p38 (1:1,000 dilution), anti-phospho p38 (1:1,000 dilution), anti-JNK (1:1,000 dilution), anti-phospho JNK (1:1,000 dilution), anti-p53 (1:1,000 dilution), anti-Cyclin B1 (1:1,000 dilution), anti-Cyclin D1 (1:1,000 dilution), anti-Cyclin E (1:1,000 dilution), anti-CDC2 (1:500 dilution), anti-Bcl-2 (1:1,000 dilution), anti-Bax (1:1,000 dilution), anti-Bak (1:1,000 dilution), anti-Mcl1 (1:1,000), anti-Bad (1:1,500 dilution), anti$\mathrm{NF}-\kappa \mathrm{B}$ (1:1,000 dilution) and anti-GAPDH (1:1,000 dilution). Subsequently, membranes were incubated with the relevant secondary antibodies (goat anti-mouse IgG-HRP or goat antirabbit IgG-HRP) at 1:10,000 dilutions at room temperature for $2 \mathrm{~h}$ in accordance with the manufacturer's instructions. Finally, the blots were detected by using enhanced chemiluminescence reagents (Immobilon ${ }^{\circledR}$ Western; Millipore Corp., Billerica, MA, USA) (31).

Subcutaneous xenograft model. Animal care was in accordance with institutional guidelines The animal study was approved by the ethics committee of Xi'an Jiaotong University, Xi'an, China. Prior to the xenograft study, an acute toxicity test was performed on mice to determine the $10 \%$ lethal dose $\left(\mathrm{LD}_{10}\right)$ and $\mathrm{LD}_{50}$ of the extracts of $M$. cochinchinensis. The $\mathrm{LD}_{10}(50 \mathrm{mg} / \mathrm{kg})$ and $1 / 2 \mathrm{LD}_{10}(25 \mathrm{mg} / \mathrm{kg})$ were then used to investigate the anti-tumor activity of $M$. cochinchinensis. Solid tumor models were developed from MDA-MB-231 cell lines. A total of $1 \times 10^{7}$ cells were suspended in $0.2 \mathrm{ml}$ culture medium without fetal bovine serum and injected subcutaneously into the right axilla of the mice. Tumors were measured 
Table I. Compounds tentatively identified in the ethyl acetate extract of seeds of Momordica cochinchinensis (Lour.) Spreng.

\begin{tabular}{|c|c|c|c|c|c|}
\hline Peak number & $\begin{array}{l}\text { Retention } \\
\text { time (min) }\end{array}$ & $\begin{array}{l}\text { Percentage of } \\
\text { the peak }\end{array}$ & $\begin{array}{l}\text { Molecular } \\
\text { formula }\end{array}$ & $\begin{array}{l}\text { Similarity } \\
\text { index }^{\mathrm{a}}\end{array}$ & Compound \\
\hline 1 & 3.319 & 6.84 & $\mathrm{C}_{6} \mathrm{H}_{12} \mathrm{O}_{2}$ & 97 & Hexanoic acid \\
\hline 2 & 5.851 & 1.62 & $\mathrm{C}_{10} \mathrm{H}_{18} \mathrm{O}$ & 93 & 2-Heptenal \\
\hline 3 & 6.325 & 4.67 & $\mathrm{C}_{9} \mathrm{H}_{14} \mathrm{O}$ & 97 & 2,4-Nonadienal \\
\hline 4 & 7.391 & 2.33 & $\mathrm{C}_{7} \mathrm{H}_{6} \mathrm{~N}_{4} \mathrm{O}$ & 87 & 1,1'-Carbonyldiimidazole \\
\hline 5 & 8.988 & 3.07 & $\mathrm{C}_{11} \mathrm{H}_{18} \mathrm{O}_{2}$ & 73 & 1-Oxaspiro[4,4]nonan-4-one \\
\hline 6 & 12.105 & 4.59 & $\mathrm{C}_{8} \mathrm{H}_{14} \mathrm{O}$ & 84 & 5,5-Dimethyl-cyclohex-3-en-1-ol \\
\hline 7 & 19.529 & 1.82 & $\mathrm{C}_{20} \mathrm{H}_{32}$ & 84 & $\begin{array}{l}\text { (E,E)-7,11,15-Trimethyl-3-methylene- } \\
1,6,10,14 \text {-tetraene }\end{array}$ \\
\hline 8 & 20.121 & 7.47 & $\mathrm{C}_{38} \mathrm{H}_{68} \mathrm{O}_{8}$ & 92 & 1-(+)-Ascorbic acid 2,6-dihexadecanoate \\
\hline 9 & 22.141 & 23.62 & $\mathrm{C}_{18} \mathrm{H}_{34} \mathrm{O}_{2}$ & 91 & 6-Octadecenoic acid \\
\hline 10 & 22.381 & 37.46 & $\mathrm{C}_{18} \mathrm{H}_{36} \mathrm{O}_{2}$ & 95 & Octadecanoic acid \\
\hline 11 & 27.371 & 3.34 & $\mathrm{C}_{35} \mathrm{H}_{68} \mathrm{O}_{5}$ & 83 & Palmitin \\
\hline 12 & 31.460 & 3.17 & $\mathrm{C}_{21} \mathrm{H}_{42} \mathrm{O}_{4}$ & 85 & Octadecanoic acid 2,3-dihydroxypropyl ester \\
\hline
\end{tabular}

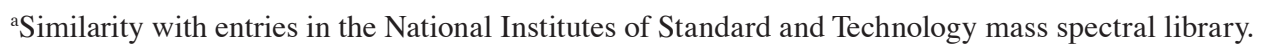

once every three days and the tumor volume was calculated from caliper measurements using the following formula: $(\text { short diameter })^{2} \mathrm{x}$ (long diameter)/2. When the tumor volume exceeded $100 \mathrm{~mm}^{3}$ (about one week after cell injection), the mice were randomly divided into three groups: ESMC ( 25 or $50 \mathrm{mg} / \mathrm{kg}$ in normal saline; $\mathrm{n}=8$ per group), or vehicle control (normal saline; $n=8$ ). All these groups were treated by intraperitoneal injection once per day. Treatment started on the day of grouping and continued for 14 days. All mice were sacrificed by cervical dislocation at the end of the experiment, and the sub-cutaneous tumors were removed and weighed. Tumor growth inhibition was calculated as: Inhibitory rate $(\%)=($ Mean final tumor weight of control group - mean final tumor weight of treatment group) / mean final tumor weight of control group $\mathrm{x} 100 \%$.

Statistical analysis. All data were obtained from at least three independent experiments and expressed as the mean \pm standard error of the mean. Comparisons between the different groups were performed using Student's $t$-test. $\mathrm{P}<0.05$ was considered to indicate a statistically significant difference between values.

\section{Results}

Identification of chemical components of ESMC2. The major chemical components of ESMC2 according to GC/MS analysis are listed in Table I. Based on the similarity index of the major peaks with entries of the NIST library, a total of 12 compounds were identified in the ethyl acetate fraction.

ESMC2 inhibits the growth of tumor cells. The effects of ESMCs on the growth of tumor cells were evaluated by MTT assay. ESMC2 showed significant anti-proliferative effects on human breast cancer MDA-MB-231 cells in a dose- and time-dependent manner, as shown in Fig. 1A. The 48-h 50\% inhibitory concentration $\left(\mathrm{IC}_{50}\right)$ of ESMC2 on MDA-MB-231 was $35.04 \mu \mathrm{g} / \mathrm{ml}$. By contrast, the other four extraction fractions (ESMC1 and ESMC3-5) did not show any obvious inhibitory effects on cancer cell growth (results not shown).

The cytotoxic effect of ESMC2 was also assessed by observing ESMC2-induced morphological changes in MDA-MB-231 cells under a phase-contrast microscope. The results revealed a significant decrease in the number of cells after treatment with ESMC2 (120 and $240 \mu \mathrm{g} / \mathrm{ml})$ as compared with that in the control group. Treatment with ESMC2 induced morphological changes of MDA-MB-231 cells, which acquired a round and shrunken shape, while retaining their polygonal structures (Fig. 1B).

ESMC2 induces breast cancer cell death. The ability of ESMC2 to induce cell death was assessed using a PI staining assay. At each of the tested concentrations (30-120 $\mu \mathrm{g} / \mathrm{ml})$, ESMC2 increased the PI uptake, indicating that the rate of cell death was increased (Fig. 2). In addition, it was observed that ESMC2 induced cell death in MDA-MB-231 cells in a dose-dependent manner. These results were consistent with those of the MTT assay to assess cell growth inhibition and viability, indicating that the anti-proliferative effect of ESMC2 on MDA-MB-231 cells may be based on its ability to kill breast cancer cells.

ESMC2 causes cell cycle arrest in G2 phase. To gain further insight into the underlying mechanisms of the cytotoxic effects of ESMC on MDA-MB-231 cells, the present study next investigated the effect of the preparation on cell cycle progression. Cells treated with 30, 60 and $120 \mu \mathrm{g} / \mathrm{ml} \mathrm{ESMC2}$ for $48 \mathrm{~h}$ displayed a G2-phase arrest. As shown in Fig. 3, the percentage of cells accumulated in G2 phase was 5.66, 10.67, 15.63 and $23.20 \%$ following treatment with $0,30,60$ and $120 \mu \mathrm{g} / \mathrm{ml}$ ESMC2, respectively. The accumulation of cells in $\mathrm{S}$ phase was maximal in the control group and declined 
A

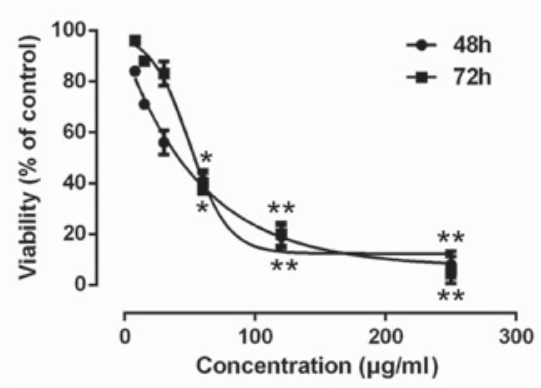

B

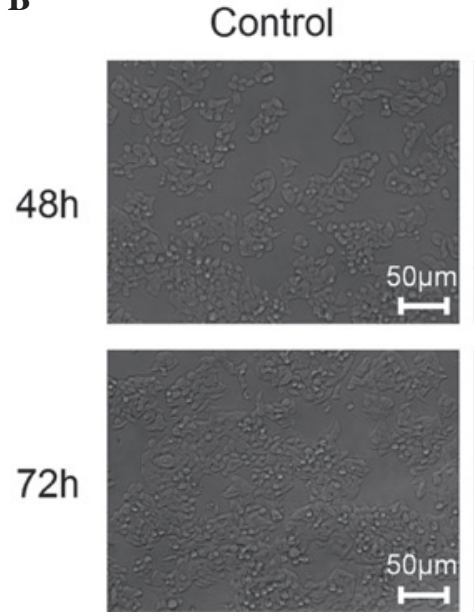

$120 \mu \mathrm{g} / \mathrm{ml}$

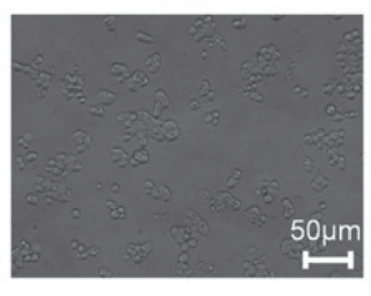

$240 \mu \mathrm{g} / \mathrm{ml}$

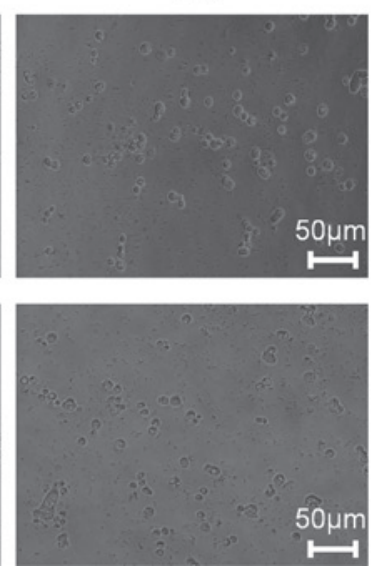

Figure 1. Effects of ESMC2 on morphological characteristics and viability of MDA-MB-231 cells. (A) Effects of ESMC2 on the viability of MDA-MB-231 cells following $48 \mathrm{~h}$ and $72 \mathrm{~h}$ as determined by an MTT assay. Values are expressed as the mean \pm standard error of the mean of at least three independent experiments. ${ }^{*} \mathrm{P}<0.05 ;{ }^{* *} \mathrm{P}<0.01$ vs. the control group. (B) Morphological changes of MDA-MB-231 cells observed by phase-contrast microscopy after treatment with 120 or $240 \mu \mathrm{g} / \mathrm{ml}$ ESMC2 for $48 \mathrm{~h}$. ESMC2, ethyl acetate extract of the seeds of Momordica cochinchinensis.

following treatment with ESMC2 in a dose-dependent manner. The S-phase population was 19.71, 16.11, 14.17 and $7.97 \%$ following treatment with $0,30,60$ and $120 \mu \mathrm{g} / \mathrm{ml}$ ESMC2 for $48 \mathrm{~h}$, and these decreases were associated with a concomitant increase in apoptosis and accumulation of cells in G2 phase. This indicated that the ESMC2-mediated death of MDA-MB-231 cells may have been initiated, at least in part, by the induction of $\mathrm{G} 2$-phase arrest.

ESMC2 increases apoptosis of MDA-MB-231 cells. To investigate the effects of ESMC2 on the induction of apoptosis, MDA-MB-231 cells were treated with ESMC2, followed by assessment of DNA fragmentation, an important characteristic of apoptosis, which can be easily distinguished by Hoechst staining. In accordance with the abovementioned results, treatment with 30,60 and $120 \mu \mathrm{g} / \mathrm{ml}$ of ESMC2 for $48 \mathrm{~h}$ led to a significant nuclear condensation or nuclear fragmentation (Fig. 4).

To confirm the effect of ESMC2 on cell apoptosis and to distinguish between apoptosis and necrosis, treated cells were stained with Annexin V-FITC and PI and analyzed by flow cytometry. A dose-dependent increase in the percentage of apoptotic cells (Annexin V-positive, PI-positive) was observed. The percentage of apoptotic MDA-MB-231 cells resulting from treatment with $0,30,60$ and $120 \mu \mathrm{g} / \mathrm{ml} \mathrm{ESMC2}$ was $14.97,24.09,32.50$ and $65.70 \%$, respectively. In parallel with this, the rate of early apoptosis and necrosis, shown in the lower right and upper left quadrants, respectively, increased in a dose-dependent manner (Fig. 5).

Furthermore, the present study examined the effect of ESMC2 treatment on the mitochondrial transmembrane potential using rhodamine 123 staining followed by flow cytometric analysis. Treatment of MDA-MB-231 cells with ESMC2 caused a decrease in rhodamine 123 fluorescence intensity from $96.42 \%$ in untreated cells to $84.13,62.98$ and $43.30 \%$ in cells treated with 30,60 and $120 \mu \mathrm{g} / \mathrm{ml}$ of ESMC2, respectively (Fig. 6). This loss of the mitochondrial membrane potential further demonstrated that ESMC2 caused apoptosis in breast cancer cells.
ESMC2 increases the expression of apoptosis- and cell cycle-associated proteins and the activation of MAPK/JNK signaling molecules. Multiple signal transduction pathways are involved in the regulation of cell cycle progression and the induction of apoptosis. The results of the present study showed that ESMC2 was able to induce G2-phase arrest; therefore, its effect on the expression of cell cycle-regulating proteins was assessed. MDA-MB-231 cells treated with ESMC2 (30, 60 and $120 \mu \mathrm{g} / \mathrm{ml}$ ) for $48 \mathrm{~h}$ were subjected to western blot analysis. Treatment with ESMC2 led to a significant increase in CDC2, Cyclin B1 and cyclin E expression, and a subsequent decrease in Cyclin D1 expression in a dose-dependent manner (Fig. 7A). Next, the expression of Bcl-2 family proteins in MDA-MB-231 cells treated with increasing concentrations of ESMC2 $(30,60$ and $120 \mu \mathrm{g} / \mathrm{ml})$ for $48 \mathrm{~h}$ was examined by western blot analysis. Treatment with ESMC2 led to a marked decrease in Bcl-2 and Mcl-1 expression and a significant upregulation of Bax, Bak and Bad expression (Fig. 7B). To further explore the underlying mechanisms of ESMC2-induced apoptosis, the effect of ESMC2 on the MAPK pathway was assessed by determining the levels of total as well as phosphorylated Erk1/2, JNK, P38 and Akt. According to western blot analysis, treatment with ESMC2 led to a significant decrease in the expression of phospho-Erk1/2, phospho-JNK, phospho-P38 and phospho-Akt, while total protein levels remained constant (Fig. 7C). The results suggested that the protein phosphorylation, and thereby their activation, was downregulated by ESMC2 in a dose-dependent manner. Further western blot experiments showed that ESMC2 was able to upregulate p53

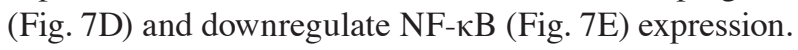

Effect of ESMC2 on the growth of MDA-MB-231 cells in athymic mice. The anti-tumor properties of ESMC2 were evaluated using an MDA-MB-231 cell xenograft model. ESMC2 inhibited tumor growth in MDA-MB-231-xenografted athymic mice in a dose-dependent manner (Table II). At the end of the study, the tumors in the group treated with ESMC ( 25 or $50 \mathrm{mg} / \mathrm{kg}$ ) were smaller and lighter compared with those in the vehicle-treated control group. The tumor growth 

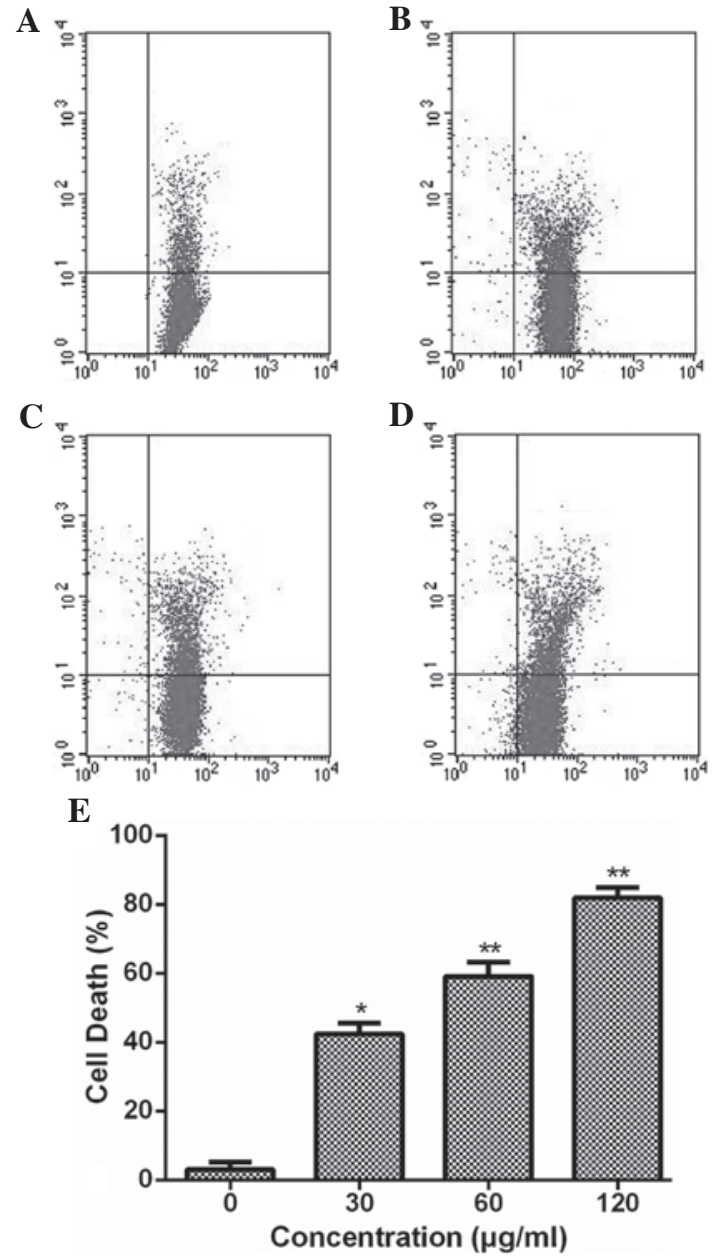

Figure 2. Cell death of MDA-MB-231 cells treated with ESMC2. Flow cytometric analysis of PI incorporation into ESMC2-treated cells and control (untreated) cells. Representative dot plots of cells treated with ESMC2 at (A) 0 , (B) 30, (C) 60 and (D) $120 \mu \mathrm{g} / \mathrm{ml}$ of ESMC2 for $48 \mathrm{~h}$, showing an increase in cell death in a dose-dependent manner as indicated by an increased PI uptake. (E) Graphs depicting the increased cell death according to the PI staining assay of ESMC2-treated MDA-MB-231 cells at the indicated concentrations as compared with that of untreated cells. Values are expressed as the mean \pm standard error of the mean of at least three independent experiments. ${ }^{~} \mathrm{P}<0.05,{ }^{* *} \mathrm{P}<0.01$ vs. the control group. PI, propidium iodide; ESMC2, ethyl acetate extracts of the seeds of Momordica cochinchinensis.

inhibition was 67.61 and $81.82 \%$ respectively. Of note, mice receiving ESMC2 showed no apparent weight loss during the experiment, suggesting that ESMC2 at the concentrations used is non-toxic to athymic mice.

\section{Discussion}

Preliminary experiments by our group have indicated that extracts of Momordica cochinchinensis Spreng. exerted an anti-cancer effect. In order to identify the active components, Momordica cochinchinensis was extracted with solvents covering a range of polarities (increasing polarity gradient of hexane, ethyl acetate, acetone, ethanol and water) via the Soxhlet extraction method. This method has the advantage that each extracted fraction contains individual compounds. The inhibitory effects of ESMCs on breast cancer cells was investigated using an MTT assay. Among the various fractions, ESMC2, which was isolated from Momordica
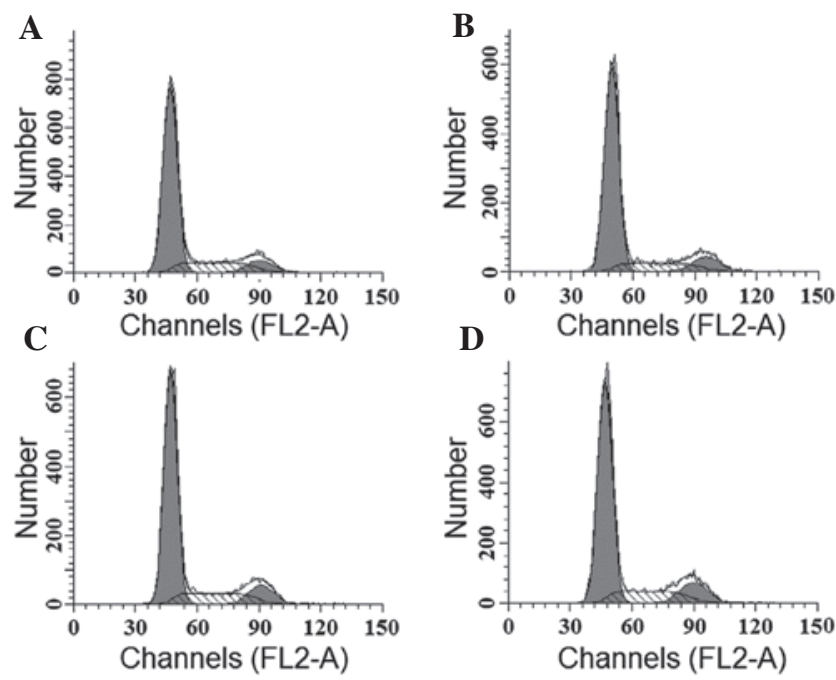

E

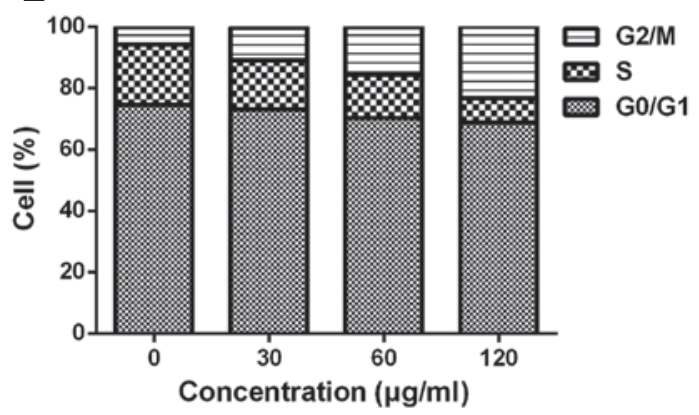

Figure 3. Effects of ESMC2 on the cell cycle distribution. MDA-MB-231 cells treated with (A) 0, (B) 30, (C) 60 and (D) $120 \mu \mathrm{g} / \mathrm{ml} \mathrm{ESMC} 2$ for $48 \mathrm{~h}$ followed by staining with PI for flow cytometric analysis. Histograms reveal the number of cells/channel (y axis) versus DNA content ( $\mathrm{x}$ axis). (E) Percentages of cells in the indicated phases of the cell cycle obtained by integration of the areas under the curves in A-D. ESMC2 treatment leads to G2-phase arrest. The data shown are representative of three independent experiments with similar results. PI, propidium iodide; ESMC2, ethyl acetate extracts of the seeds of Momordica cochinchinensis.

cochinchinensis by ethyl acetate extraction, showed significant anti-proliferative effects on cancer cells. Therefore, the present study further investigated the effects of ESMC2 on MDA-MB-231 cells as well as its possible mechanisms of action.

Cell cycle arrest and apoptosis represent two effective mechanisms involved in the induction of cell death (32). The cell cycle of somatic cells is tightly regulated by an intricate network of positive and negative signals. Much is known about the molecules involved in cell cycle control and the regulation of checkpoints to mediate cell cycle progression (33). When MDA-MB-231 cells in the exponential growth phase were treated with ESMC2, G2-phase arrest was observed, alongside the induction of apoptosis. In the cell cycle, the G2 checkpoint control mechanism ensures that the cell is ready to enter the $\mathrm{M}$ (mitosis) phase and divide. The $\mathrm{S}$ phase is associated with DNA synthesis and has a crucial role in the progression of the cell cycle. The G2 phase is therefore a key stage in the cell cycle and the target of numerous drugs (34). Positive factors regulating cell cycle checkpoints include CDKs and cyclins; a variety of cyclins, which are generated through the use of alternate transcription initiation sites, exhibit distinct expression and degradation patterns, contributing to the temporal 

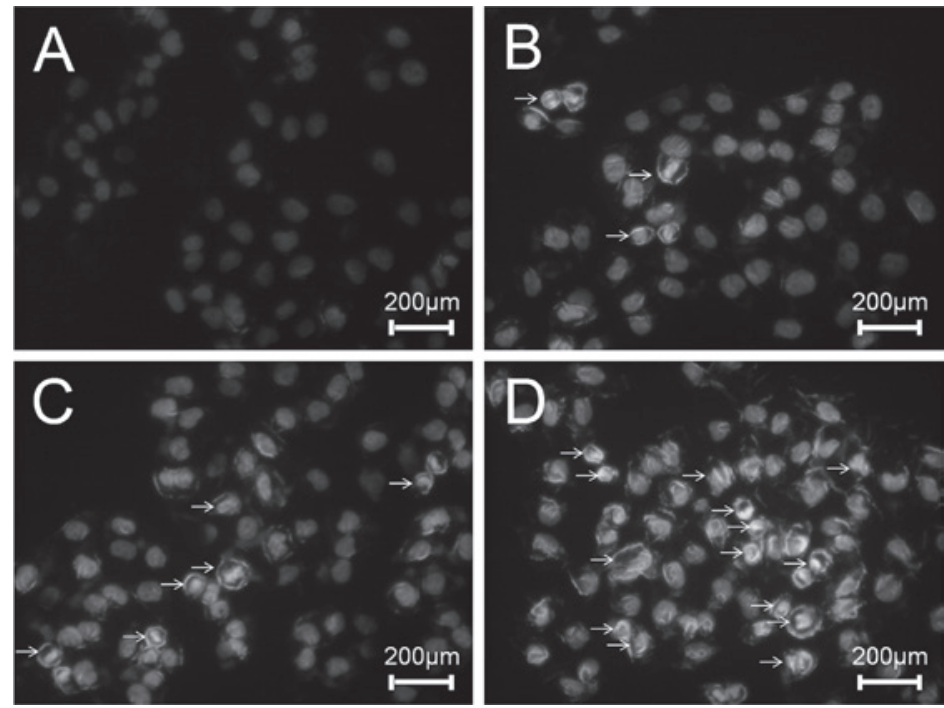

Figure 4. Treatment with ESMC2 induces apoptosis of MDA-MB-231 cells in vitro. MDA-MB-231 cells were cultured overnight in six-well plates and treated with (A) 0, (B) 30, (C) 60 and (D) $120 \mu \mathrm{g} / \mathrm{ml}$ of ESMC2 for $48 \mathrm{~h}$. ESMC2-induced apoptosis in MDA-MB-231 cells, as shown by arrows, is characterized by nuclear condensation or nuclear fragmentation after Hoechst 33258 staining. Representative images of three independent experiments are shown. ESMC2, ethyl acetate extracts of the seeds of Momordica cochinchinensis.
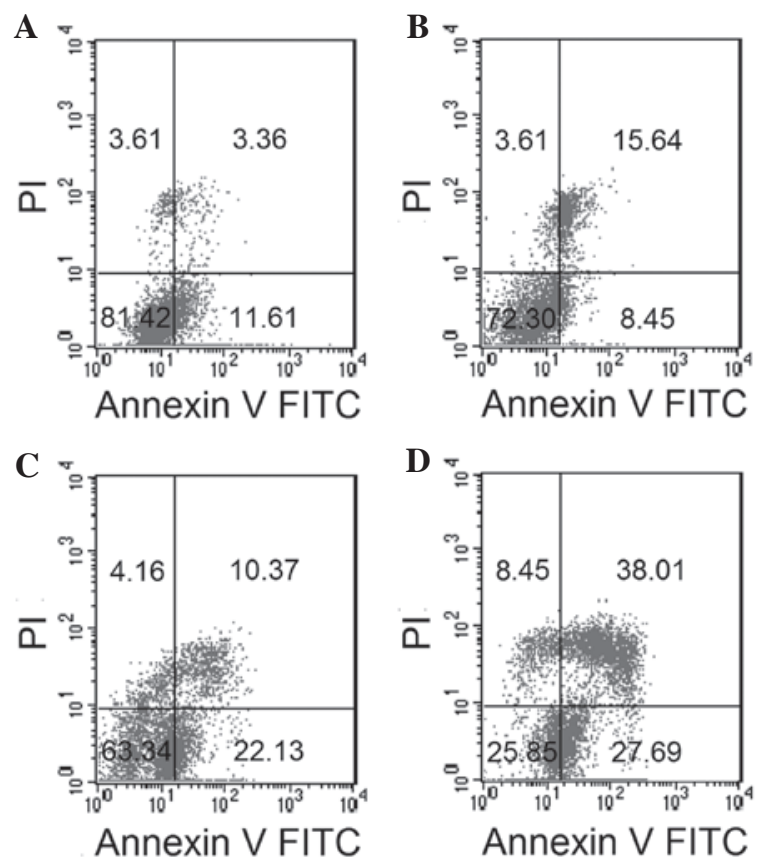

Figure 5. Flow cytometric analysis of ESMC2-induced apoptosis in MDA-MB-231 cells. Cells were treated with ESMC2 at (A) 0, (B) 30, (C) 60 and (D) $120 \mu \mathrm{g} / \mathrm{ml}$ for $48 \mathrm{~h}$ followed by staining with FITC-conjugated Annexin V and PI, and flow cytometric analysis. The flow cytometry dot plots represent Annexin V-FITC staining on the $\mathrm{x}$ axis and PI on the y axis. The numbers represent the respective cell populations in the quadrants (in per cent; viable cells in the lower left quadrant, necrotic or dead cells in the upper left quadrant, early apoptotic cells in the lower right quadrant and late apoptotic cells in the upper right quadrant). PI, propidium iodide; FITC, fluorescein isothiocyanate; ESMC2, ethyl acetate extracts of the seeds of Momordica cochinchinensis.

coordination of each mitotic event (11). In the present study, ESMC2 inhibited the proliferation of MDA-MB-231 cells, partly as a result of the accumulation of cells in $\mathrm{G} 2$ phase of the cell cycle. The S-phase population decreased, whereas the G2-phase population increased in the treated group compared
A
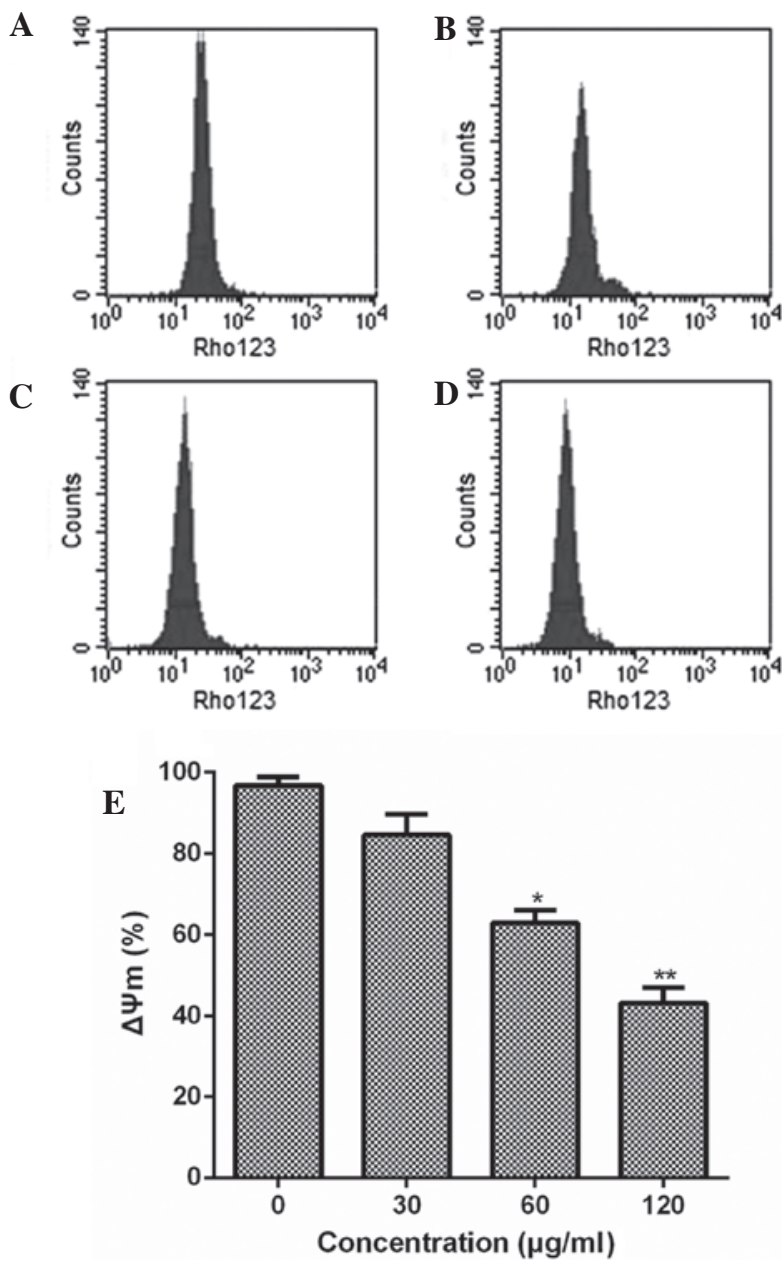

Figure 6. Effects of ESMC2 on the mitochondrial transmembrane potential as assessed by staining with fluorescent Rho 123 of MDA-MB-231 cells treated with (A) 0, (B) 30, (C) 60 and (D) $120 \mu \mathrm{g} / \mathrm{ml}$ ESMC2 for $48 \mathrm{~h}$. (E) Graph illustrating the mitochondrial transmembrane potential in MDA-MB-231 cells. Values are expressed as the mean \pm standard error of the mean of at least three independent experiments. ${ }^{*} \mathrm{P}<0.05,{ }^{* *} \mathrm{P}<0.01$ vs. the control group. Rho 123 , rhodamine $123 ; \Delta \Psi \mathrm{m}$, mitochondrial membrane potential; ESMC2, ethyl acetate extracts of the seeds of Momordica cochinchinensis. 
A
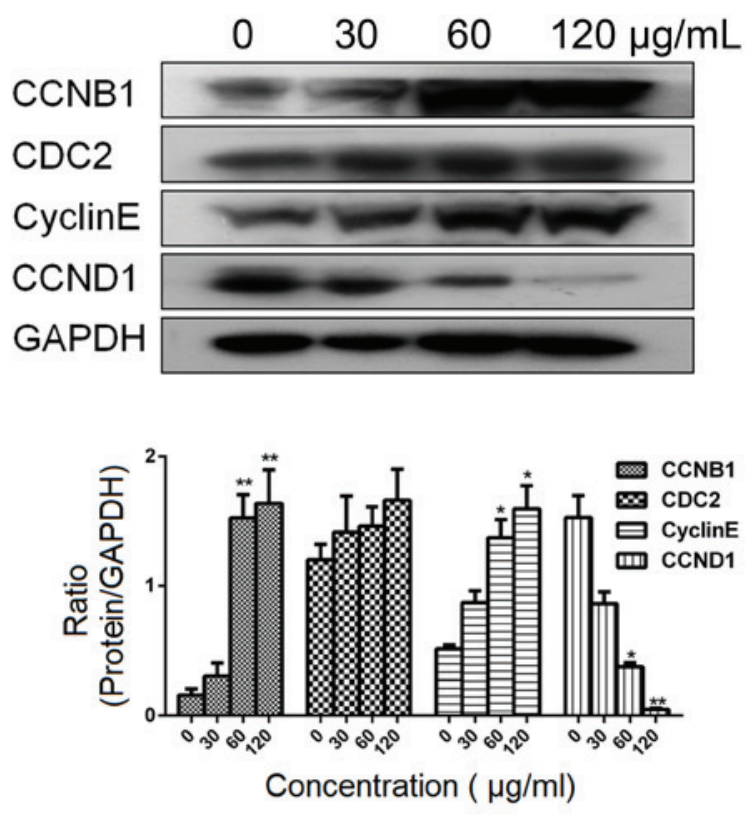

C
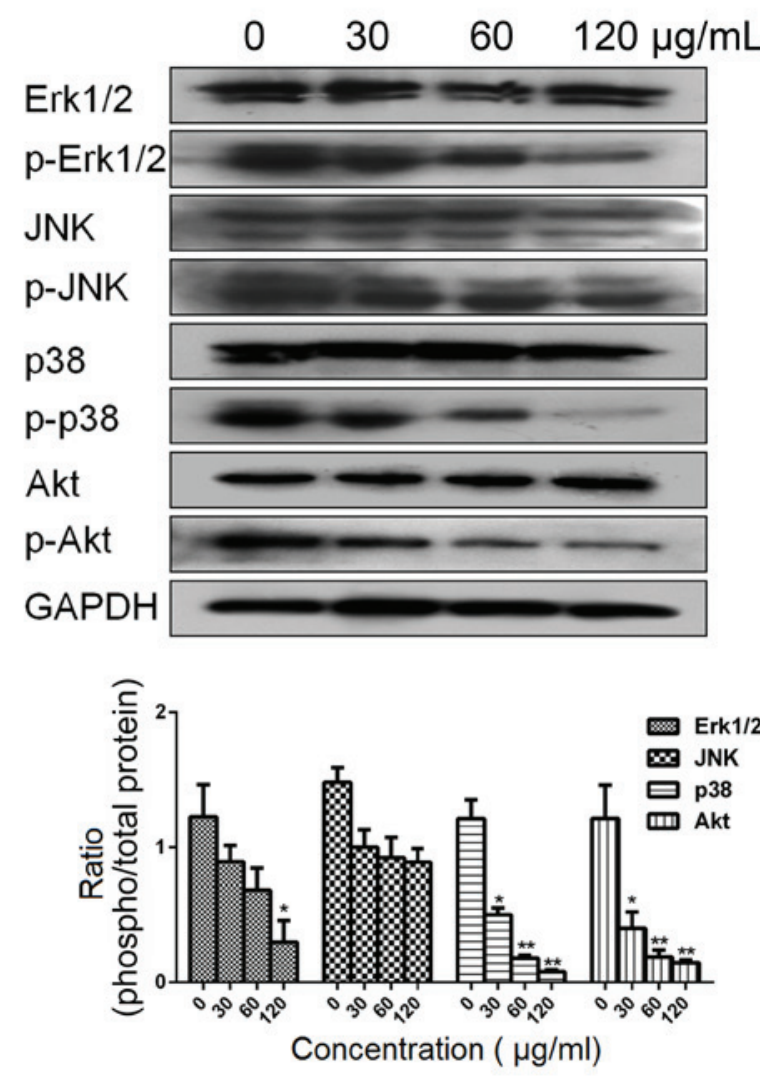

B

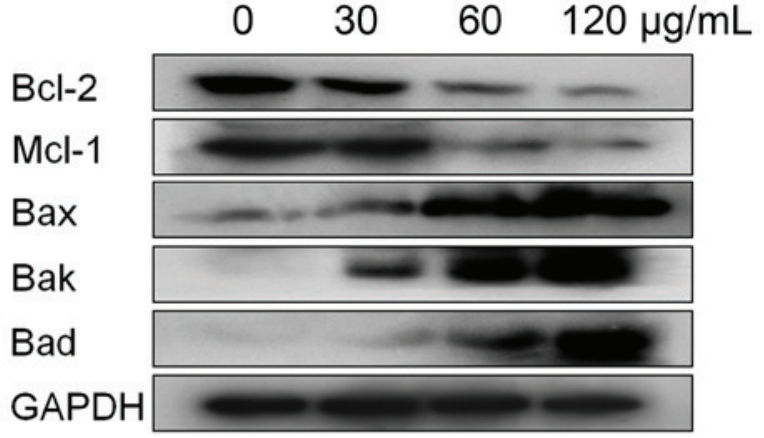

D

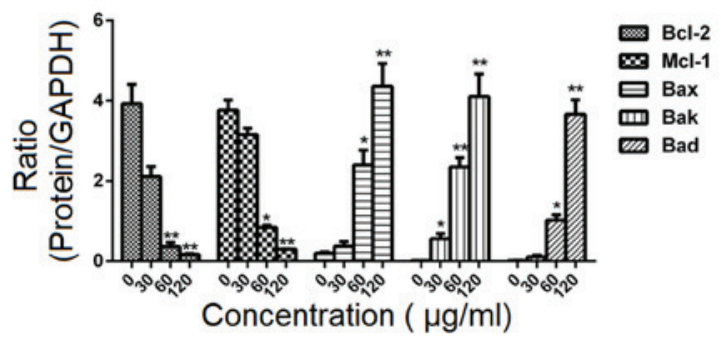

P53

$\begin{array}{llll}0 & 30 & 60 & 120 \mu \mathrm{g} / \mathrm{mL}\end{array}$

GAPDH

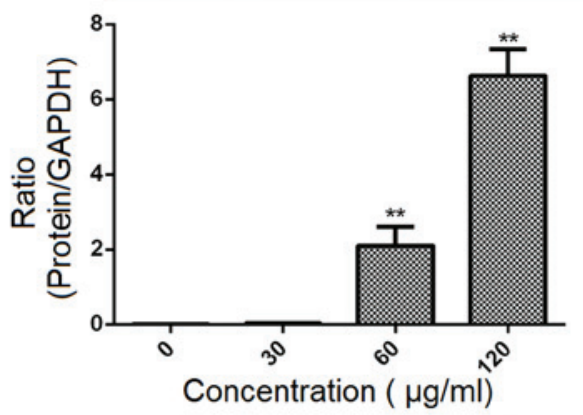

$\mathbf{E}$
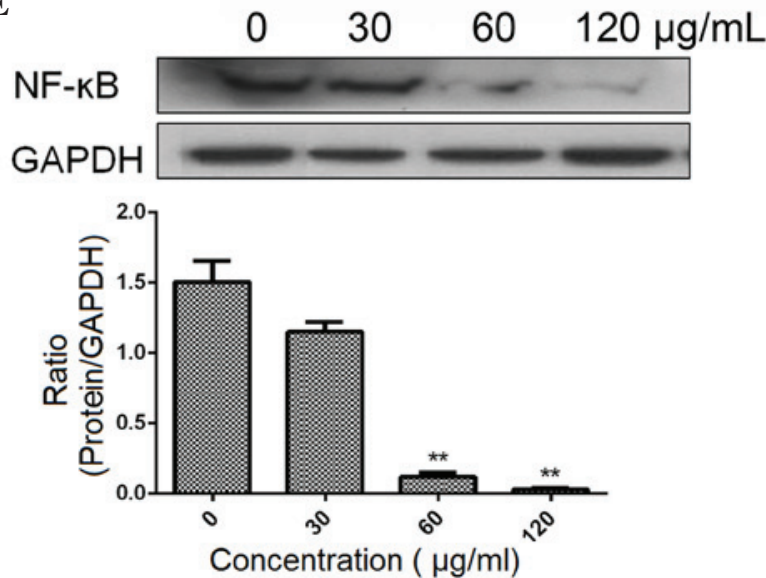

Figure 7. Effects of ESMC2 on protein expression in MDA-MB-231 cells assessed by western blot analysis. (A) Effects of ESMC2 on the expression of the cell cycle-associated proteins Cyclin D1, Cyclin B1, cyclin E and CDC2. Treatment with ESMC2 $(0,30,60$ and $120 \mu \mathrm{g} / \mathrm{ml}$ for $48 \mathrm{~h})$ increased the expression levels of Cyclin B1, cyclin E and CDC2, and down-regulated the expression of Cyclin D1 in a dose-dependent manner. (B) Effects of ESMC2 on Bcl-2 family proteins. The expression of Bax, Bak and Bad was upregulated, while the expression of Bcl-2 and Mcl-1 was downregulated. (C) Effects of ESMC2 on the levels of total Erk1/2 and phospho-Erk1/2, total JNK and phospho-JNK, total P38 and phospho-P38, as well as total Akt and phospho-Akt. Treatment of MDA-MB-231 cells with ESMC2 led to a significant decrease in the expression of phospho-Erk1/2, phospho-P38 and phospho-Akt in a dose-dependent manner, while the respective total protein levels remained constant. (D) Effects of ESMC2 on the expression of P53. (E) Effects of ESMC2 on the expression of NF- $\mathrm{kB}$. GAPDH was used as a loading control. Lanes in blots (from left to right): Cells treated with $0,30,60$ and $120 \mu \mathrm{g} / \mathrm{ml} \mathrm{ESMC} 2$. Values are expressed as the mean \pm standard error of the mean of at least three independent experiments. ${ }^{*} \mathrm{P}<0.05,{ }^{* *} \mathrm{P}<0.01$ vs. the control group. $\mathrm{CDC} 2$, cyclin-dependent kinase 1; Bcl-2, B-cell lymphoma 2; Bax, Bcl-2-associated X protein; Bad, Bcl-2-associated death promoter; Bak, Bcl-2 homologous antagonist killer; Mcl-1, myeloid cell leukemia 1; Erk, extracellular signal-regulated kinase; JNK, c-Jun N-terminal kinase; p-, phosphorylated; NF- $\mathrm{B}$, nuclear factor kappa B; ESMC2, ethyl acetate extracts of the seeds of Momordica cochinchinensis. 
Table II. Effect of ESMC2 on ZR-75-30 cells xenografted in athymic mice.

\begin{tabular}{|c|c|c|c|c|c|c|c|}
\hline \multirow[b]{2}{*}{ Group } & \multicolumn{2}{|c|}{ Body weight (g) } & \multirow{2}{*}{$\begin{array}{l}\text { Ratio of body } \\
\text { growth (\%) }\end{array}$} & \multicolumn{2}{|c|}{ Tumor size $\left(\mathrm{mm}^{3}\right)$} & \multirow{2}{*}{$\begin{array}{c}\text { Tumor } \\
\text { weight }(\mathrm{g})\end{array}$} & \multirow{2}{*}{$\begin{array}{l}\text { Tumor growth } \\
\text { inhibition (\%) }\end{array}$} \\
\hline & Start & End & & Start & End & & \\
\hline Vehicle control & $20.22 \pm 1.11$ & $22.63 \pm 2.45$ & 11.92 & $107.80 \pm 24.03$ & $223.00 \pm 42.31$ & $0.443 \pm 0.266$ & - \\
\hline ESMC ( $25 \mathrm{mg} / \mathrm{kg})$ & $20.18 \pm 0.981$ & $22.50 \pm 1.00$ & 11.50 & $104.00 \pm 17.94$ & $144.25 \pm 64.99$ & $0.143 \pm 0.098$ & $67.61 \%$ \\
\hline ESMC (50 mg/kg) & $20.00 \pm 1.16$ & $22.20 \pm 0.739$ & 11.00 & $100.25 \pm 25.86$ & $129.75 \pm 36.43$ & $0.080 \pm 0.054^{\mathrm{a}}$ & $81.82 \%$ \\
\hline
\end{tabular}

Values are expressed as the mean \pm standard error of the mean. ${ }^{a} \mathrm{P}<0.05$ versus control. ESMC2, ethyl acetate extract of the seeds of $M o$ mordica cochinchinensis.

with that in the control group. The observed G2 arrest was followed by cell growth suppression.

To identify the mechanisms leading to cell cycle arrest, series of signaling proteins were assessed using western blot analysis. These included G2/mitotic-specific cyclin-B1 (encoded by the CCNB1 gene in humans), cyclin B1, a regulatory protein involved in mitosis (35), and cyclin $\mathrm{E}$, which binds to the G1-phase-associated protein Cdk2, which is required for the transition from $\mathrm{G} 1$ to $\mathrm{S}$ phase of the cell cycle and regulates cell division (36). CDC2 remains at a constant level during the cell cycle (37). Furthermore, G0/G1-phase-regulating protein cyclin-D1, encoded by the CCND1 gene in humans, was determined (38). In the present study, treatment with ESMC2 increased the protein expression of Cyclin B1, cyclin E and $\mathrm{CDC} 2$, which explains the accumulation of cells in G2 phase of the cell cycle in MDA-MB-231 cells following ESMC2 treatment. The decrease in the number of cells in $\mathrm{S}$ phase following ESMC2 treatment was likely to be associated with the concomitant increase in apoptosis and accumulation of cells in the $\mathrm{G} 2$ phase.

Numerous apoptotic stimuli induce cell cycle arrest prior to cell death, thereby affecting the cell cycle and the apoptotic machinery (39). In the present study, apoptotic cells were distinguished by Hoechst staining, which was more intense in the ESMC2-treated groups than that in the control group. In the Annexin-V/PI assay, MDA-MB-231 cells were exposed to ESMC2 at a range of concentrations for $48 \mathrm{~h}$, leading to apoptosis in a dose-dependent manner. Bcl-2 family proteins are regulators of apoptosis (12). The Bcl-2 family of homologous proteins represents a critical checkpoint within most apoptotic pathways, acting upstream of signaling in response to irreversible damage to cellular constituents and including anti-apoptotic as well as pro-apoptotic proteins. The balance between these two classes of proteins is critical for predicting (at least in part) how cells respond to apoptotic or survival signals. In contrast to inactive Bax, which is monomeric and located in the cytosol or loosely associated with membranes, $\mathrm{Bcl}-2$ is an integral membrane protein localized to the mitochondria. It is conceivable that the signal for Bax activation emanates from the mitochondria (12). The present study showed that ESMC2-induced apoptosis was associated with the upregulation of the expression of Bax, Bak and Bad, and the downregulation of the expression of Bcl-2 and Mcl-1. These results support the notion that ESMC2 induces apoptosis by affecting the expression of Bcl-2 family proteins. This leads to the collapse of the mitochondrial membrane potential, as detected by rhodamine 123 staining, and ultimately results in apoptosis.

P53 is considered a 'guardian of the genome' and has a pivotal role in the regulation of cell cycle progression, checkpoint activation, apoptosis and repair of DNA damage. Manipulation of p53-mediated pathways is, therefore, an ongoing focus for the development of effective anti-cancer agents (19). NF- $\mathrm{KB}$ signaling has critical roles in numerous physiological and pathological processes. One function of NF- $\mathrm{KB}$ is to promote cell survival via the induction of proteins that inhibit components of the apoptotic machinery in normal and cancerous cells. In addition, continuous activation of NF- $\mathrm{KB}$ promotes cell proliferation, which is involved in the pathogenesis of numerous human cancers (20). The results of the present study showed that treatment with ESMC2 led to the upregulation of p53 and downregulation of NF- $\mathrm{KB}$ expression.

The MAPKs are important in the regulation of apoptosis. It has been originally shown that ERKs are important for cell survival, whereas $\mathrm{p} 38$ /MAPKs are stress-responsive signaling molecules and are thus involved in apoptosis (15). Cell survival is regulated by phosphoinositide 3-kinase-mediated activation of the anti-apoptotic kinase Akt. Akt in turn phosphorylates and inhibits the pro-apoptotic proteins. Akt and Erk1/2 are key junction points linking together signal transduction involved in survival and proliferation (15). In the present study, ESMC2 was shown to restrain protein phosphorylation and accordingly promote apoptosis, finally leading to the inhibition of MDA-MB-231-cell survival and proliferation.

Xenotransplant models were used to investigate whether the anti-proliferative effects of ESMC2 evidenced in vitro may be utilized to achieve growth inhibition of solid tumors in vivo. Tumor cells at the periphery of the solid tumor are characterized by their continuous and active growth. As the MDA-MB-231 cell line was most sensitive to the ESMC2 fraction in vitro, the anti-tumor effects of ESMC2 were demonstrated in the well-established MDA-MB-231 human breast cancer cell xenograft model. A significant growth delay of the sub-cutaneously xenotransplanted tumors was observed in the athymic mice treated with ESMC2 compared with that in the untreated control group. The final tumor volume and weight of the xenografts were reduced by ESMC2 in a dose-dependent manner. At the same time, no body weight loss was observed in ESMC2-treated groups compared with that in the control 
group over the entire experimental period. All these results indicated that ESMC2 exerted potent growth inhibitory and anti-tumor effects in the human xenografts with no signs of toxicity.

In conclusion, the present study was the first, to the best of our knowledge, to provide evidence that the ethyl acetate extracts of Momordica cochinchinensis inhibited the proliferation of MDA-MB-231 cells, and induced cell cycle arrest and apoptosis in MDA-MB-231 cells. Analysis of plant extracts using GC/MS has been performed previously (40). The results of the present study demonstrated that ESMC2 contains various bioactive components that may have been responsible for the inhibition of tumor cell growth and induction of apoptosis in the cancer cell line. Therefore, these results warrant further pharmacological investigation of Momordica cochinchinensis seeds with detailed phytochemical analysis. Momordica cochinchinensis is a promising herbal medicine for cancer prevention and treatment, and the results of the present study will encourage future studies to increase the knowledge on the anti-cancer potential of this food plant. A future goal of our group is to identify the active components responsible for the anti-cancer effects of this herb.

\section{Acknowledgements}

The present study was supported by the National Natural Science Foundation of China (grant nos. 81227802, 81302800 and 81370088), the National Science Foundation for Post-doctoral Scientists of China (grant no. 2013M532062), the Project of Shaanxi Star of Science and Technology (grant no. 2012KJXX-06) and the Ministry of Education's new century excellent talents supporting plan (grant no. NCET-13-0467).

\section{References}

1. Amin AR, Kucuk O, Khuri FR and Shin DM: Perspectives for cancer prevention with natural compounds. J Clin Oncol 27: 2712-2725, 2009.

2. Li M, Hou X-F, Zhang J, Wang S-C, Fu Q and He L-C: Applications of HPLC/MS in the analysis of traditional Chinese medicines. J Pharm Anal 1: 81-91, 2011.

3. Cragg GM and Newman DJ: Plants as a source of anti-cancer agents. J Ethnopharmacol 100: 72-79, 2005.

4. Parks SE, Murray CT, Gale DL, Al-Khawaldeh B and Spohr LJ: Propagation and production of Gac (Momordica cochinchinensis Spreng.), a greenhouse case study. Experimental Agriculture 49: 234-243, 2012.

5. Tsoi AY, Ng TB and Fong WP: Immunomodulatory activity of a chymotrypsin inhibitor from Momordica cochinchinensis seeds. J Pept Sci 12: 605-611, 2006

6. Kubola J and Siriamornpun S: Phytochemicals and antioxidant activity of different fruit fractions (peel, pulp, aril and seed) of Thai gac (Momordica cochinchinensis Spreng). Food Chem 127: 1138-1145, 2011.

7. Wong RC, Fong WP and Ng TB: Multiple trypsin inhibitors from Momordica cochinchinensis seeds, the Chinese drug mubiezhi. Peptides 25: 163-169, 2004.

8. Chang F, Steelman LS, Shelton JG, Lee JT, Navolanic PM, Blalock WL, Franklin R and McCubrey JA: Regulation of cell cycle progression and apoptosis by the Ras/Raf/MEK/ERK pathway (Review). Int J Oncol 22: 469-480, 2003.

9. Harbour JW and Dean DC: Rb function in cell-cycle regulation and apoptosis. Nat Cell Biol 2: E65-E67, 2000.

10. Yao Y, Zhang YW, Sun LG, Liu B, Bao YL, Lin H, Zhang Y, Zheng LH, Sun Y, Yu CL, et al: Juglanthraquinone C, a novel natural compound derived from Juglans mandshurica Maxim, induces S phase arrest and apoptosis in HepG2 cells. Apoptosis 17: 832-841, 2012.
11. Morgan DO: Principles of CDK regulation. Nature 374: 131-134, 1995.

12. Gross A, McDonnell JM and Korsmeyer SJ: BCL-2 family members and the mitochondria in apoptosis. Genes Dev 13: 1899-1911, 1999.

13. Kang S, Dong SM, Kim BR, Park MS, Trink B, Byun HJ and Rho SB: Thioridazine induces apoptosis by targeting the $\mathrm{PI} 3 \mathrm{~K} / \mathrm{Akt} / \mathrm{mTOR}$ pathway in cervical and endometrial cancer cells. Apoptosis 17: 989-997, 2012

14. Rasul A, Ding C, Li X, Khan M, Yi F, Ali M and Ma T: Dracorhodin perchlorate inhibits PI3K/Akt and $\mathrm{NF}-\kappa \mathrm{B}$ activation, up-regulates the expression of p53 and enhances apoptosis. Apoptosis 17: 1104-1119, 2012.

15. Chuang SM, Wang IC and Yang JL: Roles of JNK, p38 and ERK mitogen-activated protein kinases in the growth inhibition and apoptosis induced by cadmium. Carcinogenesis 21: 1423-1432, 2000.

16. Wada T and Penninger JM: Mitogen-activated protein kinases in apoptosis regulation. Oncogene 23: 2838-2849, 2004.

17. Yang XH, Zhou GY, Ren T, Li H, Zhang Y, Yin D, Qian H and Li Q: $\beta$-Arrestin prevents cell apoptosis through pro-apoptotic ERK1/2 and p38 MAPKs and anti-apoptotic Akt pathways. Apoptosis 17: 1019-1026, 2012.

18. Zachary I: VEGF signalling: integration and multi-tasking in endothelial cell biology. Biochem Soc Trans 31: 1171-1177, 2003.

19. Fridman JS and Lowe SW: Control of apoptosis by p53. Oncogene 22: 9030-9040, 2003.

20. Shen HM and Tergaonkar V: NFkappaB signaling in carcinogenesis and as a potential molecular target for cancer therapy. Apoptosis 14: 348-363, 2009.

21. Vogelstein B, Lane D and Levine AJ: Surfing the p53 network. Nature 408: 307-310, 2000.

22. Luque de Castro MD and Garcia-Ayuso LE: Soxhlet extraction of solid materials: an outdated technique with a promising innovative future. Anal Chim Acta 369: 1-10, 1998.

23. Luque de Castro MD and Priego-Capote F: Soxhlet extraction: Past and present panacea. J Chromatogr A 1217: 2383-2389, 2010.

24. Zheng L, He X, Ma W, Dai B, Zhan Y and Zhang Y: Ta1722, an anti-angiogenesis inhibitor targeted on VEGFR-2 against human hepatoma. Biomed Pharmacother 66: 499-505, 2012.

25. Li DD, Guo JF, Huang JJ, Wang LL, Deng R, Liu JN, Feng GK, Xiao DJ, Deng SZ, Zhang XS, et al: Rhabdastrellic acid-A induced autophagy-associated cell death through blocking Akt pathway in human cancer cells. PLoS One 5: e12176, 2010.

26. Zhang Y, Zhang J, Dai B, Wang N and He L: Anti-proliferative and apoptotic effects of the novel taspine derivative tas 41 in the Caco-2 cell line. Environ Toxicol Pharmacol 31: 406-415, 2011.

27. Li T, Zhu J, Guo L, Shi X, Liu Y and Yang X: Differential effects of polyphenols-enriched extracts from hawthorn fruit peels and fleshes on cell cycle and apoptosis in human MCF-7 breast carcinoma cells. Food Chem 141: 1008-1018, 2013.

28. Zhan Y, Zhang Y, Liu C et al: A novel taspine derivative, HMQ1611, inhibits breast cancer cell growth via estrogen receptor $\alpha$ and EGF receptor signaling pathways. Cancer Prev Res (Phila) 5: 864-873, 2012.

29. Berdowska I, Zielinski B, Fecka I, Kulbacka J, Saczko J and Gamian A: Cytotoxic impact of phenolics from Lamiaceae species on human breast cancer cells. Food Chemistry 141: 1313-1321, 2013.

30. Zhou Y, Luo W, Zheng L, Li M and Zhang Y: Construction of recombinant FGFR1 containing full-length gene and its potential application. Plasmid 64: 60-67, 2010.

31. Zhang Y, Zheng L, Zhang J, Dai B, Wang N, Chen Y and He L: Antitumor activity of taspine by modulating the EGFR signaling pathway of Erk1/2 and Akt in vitro and in vivo. Planta Med 77: 1774-1781, 2011.

32. King KL and Cidlowski JA: Cell cycle regulation and apoptosis. Annu Rev Physiol 60: 601-617, 1998.

33. Malumbres $M$ and Barbacid M: Cell cycle, $C D K s$ and cancer: a changing paradigm. Nat Rev Cancer 9: 153-166, 2009.

34. Kastan MB and Bartek J: Cell-cycle checkpoints and cancer. Nature 432: 316-323, 2004.

35. Farhana L, Dawson M, Rishi AK, Zhang Y, Van Buren E, Trivedi C, Reichert U, Fang G, Kirschner MW and Fontana JA: Cyclin B and E2F-1 expression in prostate carcinoma cells treated with the novel retinoid CD437 are regulated by the ubiquitin-mediated pathway. Cancer Res 62: 3842-3849, 2002. 
36. Lu HF, Chen YS, Yang JS, Chen JC, Lu KW, Chiu TH, Liu KC, Yeh CC, Chen GW, Lin HJ, et al: Gypenosides induced G0/G1 arrest via inhibition of cyclin $\mathrm{E}$ and induction of apoptosis via activation of caspases-3 and -9 in human lung cancer A-549 cells. In Vivo 22: 215-222, 2008.

37. Tao W, Zhang S, Turenchalk GS, Stewart RA, St John MA, Chen W and Xu T: Human homologue of the Drosophila melanogaster lats tumour suppressor modulates CDC2 activity. Nat Genet 21: 177-181, 1999.
38. Liu Q, Fu HJ, Sun F, Zhang H, Tie Y, Zhu J, Xing R, Sun Z and Zheng X: miR-16 family induces cell cycle arrest by regulating multiple cell cycle genes. Nucleic Acids Res 36: 5391-5404, 2008.

39. King KL and Cidlowski JA: Cell cycle regulation and apoptosis. Ann Rev Physiol 60: 601-617, 1998.

40. Jonsson P, Gullberg J, Nordström A, Kusano M, Kowalczyk M, Sjöström M and Moritz T: A strategy for identifying differences in large series of metabolomic samples analyzed by GC/MS. Anal Chem 76: 1738-1745, 2004. 